\title{
当教室における馬尾神経腫瘍
}

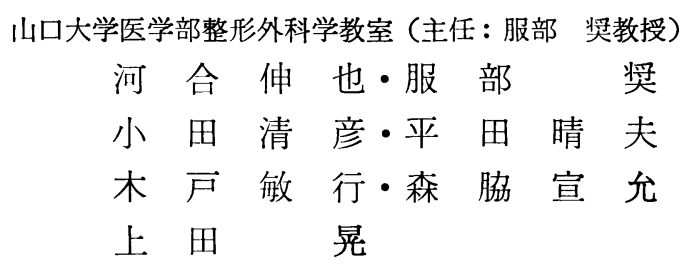

\section{Tumors of Cauda Equina In Our Clinic}

By

\author{
S. Kawai, S. Hattori, K. Oda, H. Hirata, \\ T. Kido, N. Moriwaki, and A. Ueda \\ Department of Orthopaedic Surgery, Yamaguchi University \\ School of medicine, Ube, Yamaguchi. \\ (director : Prof. S. Hattori)
}

In the thirteen-year period from October 1959 through September 1972, there were eleven patients with tumor of cauda epuina operated upon in our clinic.

It is very important to discuss the clinical features in this disease, which is greatly similiar to disc lesions.

In this paper our eleven cases are reported and for the purpose of the further discussion about this clinical pictures, fifty cases of Japanese literatures which had been recently reported in detail are gathered and investigated.

The most common symptome is low back pain and/or radiating pain on the thigh and leg, which continues for a long time.

Sensory disburbance and muscle weakness are not always recognised.

The myelogram is the most significant and valuable aid in the differential diagnosis.

In our cases there are eight neurilemmoma, two dermoid cyste and one meningioma.

\section{1. 緒言}

腰仙椎部馬尾神経領域に発生した硬膜内腫瘍は馬尾 神経腫瘍と呼ばれ，脊䯣腫瘍のなかでも特色を有した 臨床症状や経過をもっている．本邦においてもすでに 数多くの報告があり, 決して稀な疾患とは言えないだ けに, 日常多く遭遇する根性坐骨神経痛とくに腰部椎 間ヘルニア等との鑑別を要する疾患として重要なすの であり，適切な診断により充分回復が得られる故，決 して忘れることの出来ない疾患である. わたくしたち は昭和 34 年より 47 年までの 13 年間に 11 例の馬尾神 経腫瘍を経験しているが，それらの症例について報告 すると共に, 臨床像を中心として本疾患の特徵を明白 にさせたいと考えて, 最近 15 年間の 本邦報告例中著 者が涉椫し得たもので，しかも臨床症状が詳細に記載
されている 50 例と比較検討する.

\section{2. 症例}

昭和 34 年 10 月より昭和 47 年 9 月までの 13 年間に 当教室で経験した 11 症例（教室例）（表 1 ）及び 昭 和 32 年より昭和 46 年までの 本邦報告例 50 症例（文 献例）である.

\section{3. 年 令}

全症例 61 例における年令別症例数は図 1 亿示す. 20 才代，40才代に好発しており，その年令分布は 1 才 3 ケ月から 64 才に及んでいる. 教室例では 40 才 代，50才代に多く，9才より 63 才までに分布してい る. 脊髄腫浧に関する諸家の報告では青壮年層に好発 すると言われており，わたくしたちの集計した馬尾神 
表 1

\begin{tabular}{|c|c|c|c|c|c|c|c|c|c|c|c|c|}
\hline 氏＼cjkstart名 & 性別 & 年令 & \begin{tabular}{|l} 
初発よ \\
季術 \\
までの \\
期 間 \\
\end{tabular} & 主 訴 & 症状型 & $\begin{array}{l}\text { 知覚 } \\
\text { 障害 }\end{array}$ & 筋萎縮 & $\begin{array}{l}\text { dasègue } \\
\text { 氏 徵 候 }\end{array}$ & $\begin{array}{l}\text { 膀腅 } \\
\text { 直腸 } \\
\text { 障害 }\end{array}$ & 骨 変 化 & 部 位 & 腫 莇 \\
\hline & 男 & 46 & 4 年 & 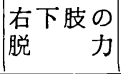 & 麻痷型 & $(t)$ & $(-)$ & $(-)$ & $(-)$ & $(-)$ & $\mathrm{L}_{1} \sim \mathrm{L}_{2}$ & 神経鞘腫 \\
\hline & 男 & 9 & 10力月 & 跛 行 & 疼痛型 & $(+)$ & $(+)$ & $\begin{array}{l}\text { 右 } 120^{\circ} \mathrm{C}(+) \\
\text { 左 } 160^{\circ} \mathrm{C}+\mathrm{C}\end{array}$ & $(-)$ & $(-)$ & $\mathrm{L}_{4} \sim \mathrm{L}_{5}$ & $\begin{array}{l}\text { 表皮㥞 } \\
\text { 震 腫 }\end{array}$ \\
\hline & 女 & 51 & 13 年 & 歩行障害 & " & $(t)$ & $(+)$ & $(-)$ & $(+)$ & $\begin{array}{l}\mathrm{L}_{2} \sim \mathrm{S}_{2} \text { に亘り } \\
\text { 脊椎管腔を它心 } \\
\text { に広範にして高 } \\
\text { 度 }\end{array}$ & $\mathrm{L}_{2} \sim \mathrm{S}_{1}$ & 骮直膜腫 \\
\hline & 男 & 39 & 3 力月 & $\mid$\begin{tabular}{|} 
腰 \\
㾏下肢痛
\end{tabular} & " & $(+)$ & $(+)$ & $(-)$ & $(-)$ & $(-)$ & $\mathrm{L}_{3}$ & 神経鞘腫 \\
\hline & 女 & 18 & 4 力月 & 腰 痛 & " & $(-)$ & $(-)$ & $\begin{array}{ll}\text { 右 } & 90^{\circ}(+) \\
\text { 左 } & (-)\end{array}$ & $(-)$ & $(-)$ & $\mathrm{L}_{3} \sim \mathrm{L}_{4}$ & |皮様震腫 \\
\hline & 男 & 43 & 2 年半 & " & " & $(-)$ & $(-)$ & $(-)$ & $(-)$ & $\begin{array}{l}\text { 椎弓根間 の } \\
\text { 軽度拡 大 }\end{array}$ & $\mathrm{L}_{1}$ & 神経鞘腫 \\
\hline & 男 & 63 & 1 年半 & 左䌓部痛 & " & $(-)$ & $(-)$ & $\left|\begin{array}{c}\text { 右 } 100^{\circ}(+) \\
\text { 左 } 120^{\circ}(+)\end{array}\right|$ & $(-)$ & $(-)$ & $\mathrm{L}_{4}$ & " \\
\hline & 男 & 45 & 1 年 & 左下肢痛 & " & $(+)$ & $(-)$ & $\left|\begin{array}{l}\text { 右 } 120^{\circ}(+) \\
\text { 左 } 115^{\circ}(+)\end{array}\right|$ & $(-)$ & $(-)$ & $\mathrm{L}_{3} \sim \mathrm{L}_{4}$ & " \\
\hline & 男 & 29 & 6 力月 & 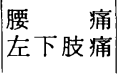 & " & $(+)$ & $(+)$ & $\left|\begin{array}{l}\text { 右 } 105^{\circ}(+) \\
\mid \frac{1}{1} 100^{\circ}(+)\end{array}\right|$ & $(-)$ & $\begin{array}{l}\text { 椎弓根間の拡大 } \\
\text { 椎体後面の陥没 }\end{array}$ & $\mathrm{L}_{4} \sim \mathrm{L}_{5}$ & " \\
\hline & 女 & 43 & 8 力月 & $\mid$\begin{tabular}{|r} 
腰 \\
痛下肢痛
\end{tabular} & " & $(\rightarrow)$ & $(-)$ & $\mid \begin{array}{l}\text { 右 } 120^{\circ}(+) \\
\text { 左 } 120^{\circ}(+)\end{array}$ & $(-)$ & $(-)$ & $\mathrm{L}_{3}$ & " \\
\hline & 男 & 50 & 2 力月 & " & " & $(-)$ & $(-)$ & $\mid \begin{array}{l}\text { 右 } 120^{\circ}(+) \\
\text { 左 } 120^{\circ}(+)\end{array}$ & $(-)$ & $(-)$ & $\mathrm{L}_{4} \sim \mathrm{L}_{5}$ & " \\
\hline
\end{tabular}

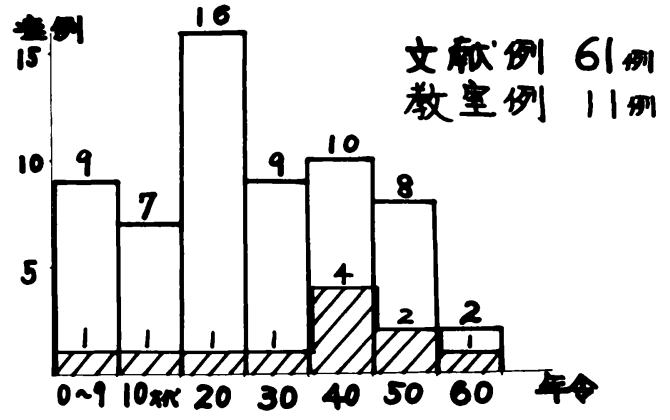

図1 年令別症例数

経腫瑒むほぼ同様に青壮年層に頻発しているが，10才 以下にも 9 例 (15\%) の症例があることは注目すべき であろう.

\section{4. 性別}

全症例中男性 39 例, 女性 21 例, 不明 1 例であり, 教室例では男性 8 例, 女性 3 例となり, 男性に多い傾 向を有している. 小川 (1958) は脊髅腫湯について男 女間に差を認めず，武内（1960）は女性より男性に 多くみられたと述べている，馬尾神経腫場としては Toumey（1950）は 48 例中全く男女間任差を認めて いない.

さててれらの症例を年令別性別に分析してみると， 男女比は 10 才以下 $8: 1,50$ 才代 $6: 2 ， 40$ 才代 $7: 2$ と男女間の差が認められているが，その他の年代層に は大差はみられない。

\section{5. 臨床 症 状}

各例の主訴を分類してみると, 腰痛 $35.9 \%$, 腰痛十

下肢痛 $21.8 \%$, 下肢痛 $10.9 \%$, 歩行障害 $10.9 \%$, 下 
肢運動障害 $7.8 \%$ の順となり, 何らかの疼痛を主訴之 しているあのが $73.4 \%$ と圧倒的に多く，麻瘏症状を 主訴之するものは $26.5 \%$ にすぎない，教室例におい ては腰痛十下肢痛の 4 例が一番多く, 疼痛を主訴とす るものは 8 例 $72.7 \%$ とはり圧倒的に多い.

臨床症状の経過を i）疼痛が主たる症状となるも の (疼痛型), ii) 麻㾝症状が主たる症状となるもの (麻㽻型), iii) 疼痛型十麻疸型の混合したもの（混 合型）の 3 つに大別すると，i）疼痛型 $76.3 \%$, ii) 麻疸型 $16.4 \%$, iii） 混合型 $7.3 \%$ となり，その経過 においても殆んど疼痛が症状の主体をなしている。し かも頌固な疼痛が長期にわたり持続するか又は少しつ つ増悪しており, 症状があまり変動しないてとが特徴 である. 更に腰部椎間板ヘルニアに比して両側性に疼 痛を訴えるものが多い，しかしながら全経過中全く疼 痛を訴えていないあのが 4 例存在する. 教室例におい ても同様に疼痛型が 9 例と大部分を占めているが, 全 く疼痛を訴えていない横川例もある.

知覚障害については有 $67.8 \%$ ，無 $32.1 \%$ \%ある. 小川 (1959) は知覚障害はすべての脊髄腫湯に認めら れると報告している, 馬尾神経腫湯に関しては診断さ え早ければ知覚障害を来たさない症例むみられてお り, Allen (1930)は $23 \%$ に知覚障害を認めていない.

わたくしたちの集計した馬尾神経腫場中, 知覚障害 の無い症例について初発より手術までの期間は平均 1 年 2 ケ月であり, 全症例の平均より 1 年 5 ケ月早い. ただ注意すべきことは岩原（1956）も指摘する如く， 腰椎穿刺後には知覚障害が出現又は上界の上昇あるい は鮮明化してくる症例がしばしば認められる.

Lasègue 氏徵候は陽性率も高く，86.5\%と高率に 認めいる．それが臨床的に腰部椎間板へルニアとの鑑 別を一層困難する由縁かも知れない.

筋萎縮は確実は陽性であると認めたものは $32.0 \%$ にすぎない。

膀胱直晹障害は有が少なく，無は $86.5 \%$ に達して いる．教室例にても 13 年の経過を有して高度の骨破 壊之両下肢麻酔を体たした土手例にみられるのみであ る.

\section{6. 期 間}

初発より手術までの期間は症例により非常にまちま ちであり, 1 ケ月〜 25 年にわたり, 平均 2 年 7 ケ月で ある (図 2 ). しかし 2 年以内 43 例 $74.1 \%, 2$ 年以

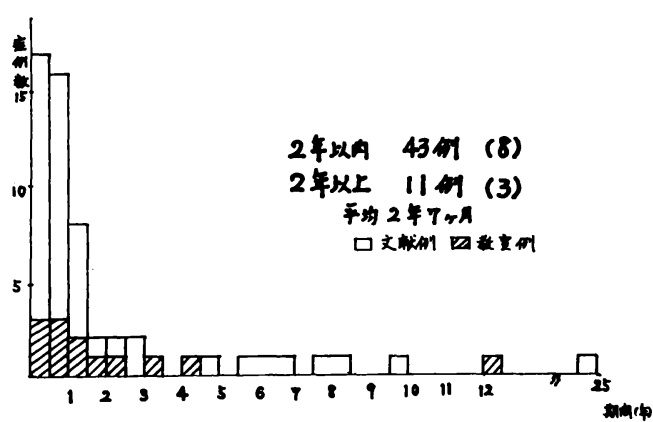

図2初発より手術までの期間

上 11 年で，その殆んどは 2 年以内に手術を行ってい る. 教室例は 2 年以内 8 例, 2 年以上 3 例となってい るが, 平均 2 年 2 ケ月である. 腰仙椎は管腔が解剖学 的に広いため, 症状の発現と進行が遅れると言われ， 小川 (1958) は馬尾神経腫瘍の多くは 2 年以上のもの が多いと述べ, Toumey (1950) は平均 2 年 1 ケ月で あると報告している.

既往の診断は根性坐骨神経痛, 腰部椎間板へルニア が最も多く, 骨盤牽引, 注射や内服等の加療を行って いる. その他ヒステリー, 関節炎, 春䯙炎等の病名も みられる.

\section{7. レントゲン所見}

単純レ線にて脊椎の 変化を認める症例は $21.4 \%$ ある. 教室例においても 3 例の変化を認めているが, 河野例 ( 2 年半) は椎弓根部の骨萎縮之椎弓間距離の 拡大ट椎体後面の陌没を認め, 土手例 (13 年) では $\mathrm{L}_{2} \sim \mathrm{S}_{2}$ にわたり脊椎管腔を中心とした広範にして高 度な骨萎縮を認めている. 脊椎の変化をみる症例につ いて初発より手術までの平均期間は 5.5 年であり, 長 期経過例にみられるのは勿論であるが， 1 年以内が 4 例存在していることは注目に価する。しかし腫瘍の発 生時期を把握することが無理であるので, てれらの数 值は必ずしも腫瘍存在時期に比例するとは考え難い.

\section{8. 診断}

Cohen and Kaplan (1943)む述べる如く，馬尾神 経腫瘍之腰部椎間板へルニアとの臨床像は非常に類似 しており，その臨床的鑑別は容易でない，馬尾神経腫 瘍では疼痛は頑固で, 症状の変動がなく, 安静を保持 しても軽快しない例が多く認められ，又その症状は両 側性であるととが多い.しかしながら前述したように 
全経過中疼痛を全く訴えない症例も認められており， 特徵的な症状をひきだすことは困難である．長期にわ たり一定の症状を訴え続けるか, 又は少しづつ増悪す る症例にはたとえ神経学的徴候が揃っていなくとも充 分注意を要する. ミエログラフィーでは殆んどの症例 が騎跨状ないしはそれに近い陰影を呈しており，てれ により始めて馬尾神経腫瘍と診断された症例が多い.

\section{9. 腫釾高位}

腫瘍の高位別分類は困 3 に示す. $\mathrm{L}_{4}>\mathrm{L}_{3}>\mathrm{L}_{5}>\mathrm{L}_{2}>$ $\mathrm{L}_{1}>\mathrm{S}_{1}$ の順で, $\mathrm{L}_{4} \sim \mathrm{L}_{3} \sim \mathrm{L}_{5}$ の部位に好発している. 教室においても同様に $\mathrm{L}_{4}, \mathrm{~L}_{3}, \mathrm{~L}_{5}$ に頻発している.

\section{0. 腫湯の組織学的分類}

文献例では表皮様囊腫が 25 例と一番多く，次いが 神経鞘腫 18 例，神経膠腫 3 例の順に多く，教室例で は神経鞘腫 8 例, 表皮様囊腫 2 例, 骾膜腫 1 例で あ る.乙れは文献的に脊髄腫瘍の中では神経鞘腫が圧倒 的に多く，比較的珍しい表皮様囊腫が腰仙部に多発す るため，好んで表皮様囊腫が報告されたものと推察さ れる. 実際 Toumey (1950) によれば, 48 例の馬尾 神経腫瘍中神経鞘腫 16 例，神経膠腫 9 例であり，表 皮様囊腫は報告されていない。 そこで神経鞘腫と表皮 様襄腫との真の比は把握し難く, 今後の調査によるも のと考える．ちなみに泰䯣腫瘍の全日本例における組 織学的分類との比較を表 2 に示した.

表皮様囊腫の成因は先天的要因，後天的因子等種々 な報告がなされているが，わたくしたちの集計した症 例の中より表皮様囊腫之神経鞘腫との年令別発生頻度 を比較してみると, 神経鞘腫は平均 37.8 才, 表皮様 襄腫は 21.6 才とかなり 差が認められた，当教室例に おいても表皮様囊腫を山本例 9 才, 中尾例 18 才と若 年者に発生しており，神経鞘腫は 29 才〜 63 才を占め ている．小川 (1958) は神経鞘腫発生の平均年令は 36.9 才であると報告しており，阪本 (1968) は脊髄 腫瘍としての 表皮様囊腫 46 例を集計しているが， そ の平均年令は 24.9 才であり，わたくしたちの症例と ほぼ同様の値を示している.

\section{1. 結 語}

1) 昭和 34 年 10 月より昭和 47 年 9 月までの 13 年 間に当教室で 経験した 馬尾神経腫瘍 11 例について報 告すると共に 最近 15 年間の 本邦報告例中臨床症状の

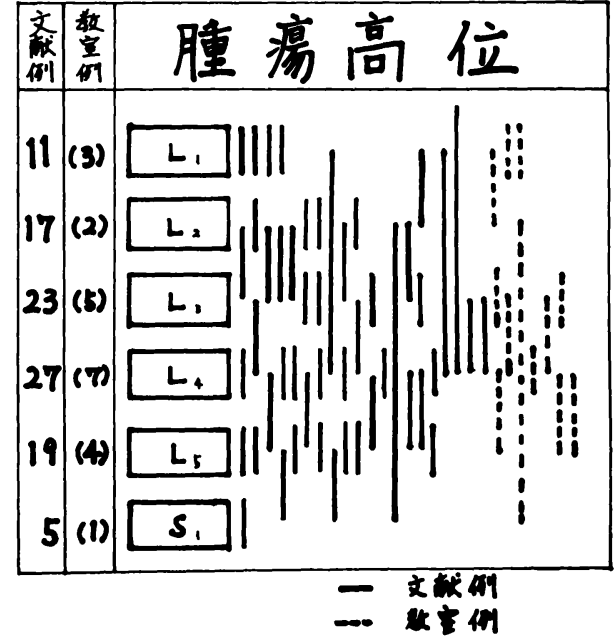

図 3

表 2 腫瘍の組織学的分類

\begin{tabular}{|c|c|c|c|c|}
\hline & \multicolumn{2}{|c|}{ 脊咀腫 晹 } & \multicolumn{2}{|c|}{ 馬尾神経腫 } \\
\hline & \begin{tabular}{|c|} 
天 览 \\
全日本例 \\
1959
\end{tabular} & \begin{tabular}{|c|c|c|} 
武 \\
全本例 \\
1960
\end{tabular} & $\begin{array}{r}\text { 文 献 } \\
1957 \sim 272 \\
1972\end{array}$ & $\begin{array}{r}\text { 教 室 } \\
1959 \sim 2 \\
1972\end{array}$ \\
\hline 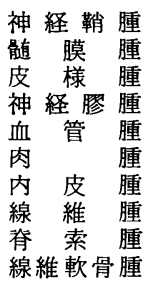 & $\begin{array}{r}199 \\
54 \\
13 \\
41 \\
25 \\
27 \\
21 \\
14 \\
3\end{array}$ & $\begin{array}{r}159 \\
40 \\
11 \\
30 \\
33 \\
30 \\
26 \\
14\end{array}$ & $\begin{array}{r}18 \\
1 \\
25 \\
3\end{array}$ & $\begin{array}{l}8 \\
1 \\
2\end{array}$ \\
\hline 合 & 517 & 508 & 50 & 11 \\
\hline
\end{tabular}

詳細な記載があるすのを 50 例渉猟し，これら 61 例よ り主として臨床症状を中心として比較検討した。

2）年令は 1 才ケ月より 64 才にわたり, 青壮年 首に好発している. 男女差はやや男性に多い傾向を有 している.

3）臨床的には疼痛が症状の主体となり, 腰痛又は 下肢痛が長期にわたり持続するかあるいは少しづつ増 悪し, 安静にてあ軽快せずしかも両側性であれば本疾 患が疑がわしいが, 臨床的に腰部椎間板ヘルニアとの 鑑別は困難であり，結局ミエログラフィーで診断され ることが多い.

4）症状の初発より手術までの期間は平均 2 年 7 ケ 月である.レ線的に脊椎の異常を認めるものは 21.4 
\%で，長期経過例に多い.

5）腫瘳は高位別には $\mathrm{L}_{3}$ を中に頻発し，組織学的 には表皮様囊腫, 神経鞘腫が多い.

（症例提供に御協力いただいた伊藤孝博士，小川省 吾博士及び平田 淳博士に深甚なる感謝の意を表しま す.)

\section{文献}

1）岩原：日整会誌. $8: 373,1933$.

2) 砂田：治療. 35:1279, 1953.

3）岩原：日本外科全書. $12: 174,1956$.

4）田中：脳と神経. 8: 485, 1956.

5）島本：日整会誌。 $57: 126,1956$.

6) 野島：日外宝函. $26: 826,1957$.

7）宇田川：日整会誌. 31: 181, 1957.

8）浦山：日整会誌. $31: 831,1957$.

9）小林：日整会誌. $32: 995,1958$.

10）伊藤：日外宝函. $28: 645,1958$.

11）牧山：中部整災誌. 1:148, 1958.

12）児玉：中部整災誌。1 : 305, 1958.

13) 小川: 医学研究. $28: 2258,1958$.

14）天児：臨と研. $36: 1583 ， 1959$.

15）黒坪: 芹海道整災誌. $5: 201,1959$.

16）桐田：中部整災誌. $2: 688,1959$.

17）木村：中部整災誌. 2: 1016, 1959.

18) 土田：日外宝函. $28: 1890,1959$.

19）野口:日整会誌。34:507, 1960.

20）森田：日整会誌. 34：1614，1960.

21）湯川：日整会誌. $34 ： 1614,1960$ 。

22）武内：整形外科. $11: 375,1960$.

23）五十嵐：北海道整災誌。 $6: 95,1960$.

24）加藤：日外会誌. $61: 308,1960$.

25) 吉峯: 中部整災誌. 3:954, 1960.

26）松田：中部整災誌. 3:956, 1960.

27）蒲原：東北整災紀要. $4: 221,1960$.

28）三瓶：整形外科. $12: 439,1961$.

29）宮本：整形外科. 12：1180, 1961.

30）笠井: 整形外科. $13: 61,1962$.

31）貝山：東北整災紀要. $5: 211,1962$.

32）菊地：東北整災紀要. $6: 88,1962$.

33）福田：中部整災誌. $5: 222,1962$.
34）柏葉：日外会誌. $63 ： 657,1962$.

35) 吉峯：整形外科：14:212, 1963 .

36）朝田：中部整災誌。 $7: 48,1964$.

37) 竹多: 中部整災誌. $7: 560,1964$.

38）牧：脳と神経. $16: 321,1964$.

39）整形外科. $15: 448,1964$.

40）笠井：整形外科. $15: 979,1964$.

41）浅井: 整形外科. $16: 612,1965$.

42）船山：整形外科. $16: 1223,1965$.

43）細川: 整形外科. $17: 136,1966$.

44）今井: 整形外科. $17: 555,1966$.

45）山崎: 整形外科. $17: 540,1966$.

46) 加藤：整形外科. $18: 219,1967$.

47）日比野：中部整災誌. 10:734，1967.

48）森田：整形外科と災害外科. $18 ： 133,1968$.

49）沢井：中部整災誌. $11: 218,1998$,

50）干田：整形外科と災害外科. $17: 108,1967$.

51）河原：整形外科. $20: 1579,1969$.

52）杉浦：整形外科. $22: 482,1971$.

53) Allen, I. M. : J. and Psychopathol, 11, 111, 1930.

54) Cohen, I and Kaolan, A. : Am. J. Surg., $60,36,1943$.

55) Toumey, J. W. : J. B. J. S., $32-$ A, 249, 1950.

56) Blockey, N. J. and Schorotein, J.: J. B. J. S., 43-B, 556, 1961.

57) Nicholas et al: J. Neurosurg., 19, 754, 1962.

58) DA Roza, A. C. : J. B. J. S., 46-B, 8, 1964.

59) Tachdjiam, M. O. and Maztom, D. D. : J. B. J. S., 47-A, 223, 1965.

追 加 九州労災病院 川嶌 真人 我々は馬尾神経鞘腫を完全に摘発したあと再発した 1 例を経験しているが, 手術症例の再発数がどの程度 あるでしょうか.

解 答山学整形外科 河合 伸也

腫瘍の再発に関して：当教室例では経験していない が, 文献的には数例認められている. 